\title{
Amerusija. Dvokulturnost i sloboda (Govor prilikom preuzimanja nagrade „Liberty” 2000.)
}

Članak je zadržan u integralnom obliku i odstupa od standardnog načina citiranja i navođenja izvora koji se primjenjuje u [sic]-u[ ${ }^{[1]}$

\section{1.}

Dugo su se ruska i američka kultura percipirale kao potpuno suprotne, građene na proturječnim idejama: kolektivizmu i individualizmu, jednakosti i slobodi, na pojmovima komunalnos ${ }^{[2]} \mathrm{i}$ „privacy”. Kako bismo se razumjeli, potrebno je primijetiti isti oksimoron u samom izrazu „ruskoamerička kultura”, kao i u izrazu „crna ovca”. Mi se, ruski Amerikanci, nalazimo „na kraju perspektive koja iščezava", u točki konvergencije suprotnosti i dužni smo ih iznova razrješavati sami u sebi, u svojem iskustvu i stvaralaštvu. Magnetno polje rusko-američke kulture nabijeno je svim onim intelektualnim i emocionalnim proturječjima koja su donedavno spomenute kulture činile neprijateljima i suparnicima.

Dakle to je, prema svojem potencijalu, zapravo velika kultura koja ne pripada u potpunosti ni američkoj, a ni ruskoj tradiciji, već nekoj fantastičnoj kulturi budućnosti, onoj Amerusiji koja je prikazana u Nabokovljevoj Adi. Rusko-američka kultura ne može se svesti na svoje zasebne komponentne, već ih nadrasta, poput krošnje, na kojoj će se daleko razgranate grane zajedničkog indoeuropskog drveta jednom ponovno ispreplesti, spoznati svoje srodstvo, baš kao što se u ruskoj riječi sam i engleskoj same mutno prepoznaje srodstvo indoeuropskih korijena.

Ujedinjene u svojim najdubljim korijenima te se kulture mogu ponovno ujediniti u svojim udaljenim mladicama i izdancima, a upravo rusko-američka kultura može biti nagovještaj i prototip takvog budućeg jedinstva. 
Kada zamišljam ruskoga Amerikanca, vidim sliku intelektualne i emocionalne širine koja bi u sebi mogla ujediniti analitičku suptilnost i praktičnost američkog uma i sintetičke sklonosti, nadarenost za mistiku ruske duše. Sjediniti rusku kulturu zamišljene melankolije, iskrene čežnje, svijetle tuge i američku kulturu hrabrog optimizma, vjere u sebe i druge...

Nehotice se prisjećamo Dostoevskog - „Širok je čovjek, čak preširok, ja bih ga suzio”[3] Ali čovjek o kojem ja govorim, Amerikano-Rus, još je širi, jer mu se u srcu ne bori samo Bog s vragom, kao u srcima svih ljudi, već se bore i različita poimanja Boga i vraga.

Dvojakost ljudske prirode umnožava se razlikom kulturalnih komponenti tog tipa.

S američke točke gledišta glavno je zlo u diskrepanciji ciljeva i sredstava. Zamisao je neupitna, a poteškoće se pojavljuju tek u procesu njezina ostvarenja. No ako se uloži potreban trud, tipična američka ideja bez poteškoća će se pretvoriti u jednako tipičan američki uspjeh. Lijenost, pokornost, pasivnost, fatalizam, nedostatak osobne inicijative ono su što kvari rusku povijest u očima Amerikanaca.

A s ruske točke gledišta, naprotiv, glavna opasnost nalazi se u samoj ideji. Najstrašnije kod utopija jest to što se one obistinjuju. Stoga je moralno štetna upravo uvjerenost ohologa čovjeka da će se sve dogoditi upravo onako kako je on to zamislio. Iskustvo ruske povijesti ironičnije je. Skriveni demon izobličava dobre ljudske ciljeve: „Htjelo se što je moguće bolje, a dogodilo se što i uvijek.”

U Rusiji se cijene velikodušnost, otvorenost, drugarstvo, smjelost, junaštvo, altruizam. U Americi dominira drukčiji set vrlina: točnost, predanost, poštenje, učinkovitost, srdačnost, tolerancija, odrješitost. Amerusi gledaju na svijet dvama parovima očiju, što im pruža sposobnost percipirati ga konveksno. Sve ima svoju cijenu: u slučaju nepravilnog preklapanja projekcija moguć je kulturalni „strabizam” - vrtoglavica i mučnina dvokulturnosti. Svijet se percipira volumno, no istovremeno se udvostručuje, pliva pred očima. On nema jedan, već dva centra, nije okrugao, već eliptičan svijet, koji nas rasteže na dvije strane, stvara dvostruko opterećenje.

\section{2.}


Osobito cijenim to što nagrada nosi ime „Sloboda”, Liberty. Shvaćanje „slobode” u ruskom jeziku neodvojivo je od shvaćanja „svojine” jer dvije riječi potječu od istog korijena, koji označava „svoj”, „osobit”, „biti svojim”. Samo bi sumanuta ideologija slobodu mogla shvaćati kao oslobađanje od svojine, lišavanje prava na svojinu; došavši u Ameriku, zajedno s pravima na svojinu, prvi smo put okusili političku slobodu. No danas bih htio govoriti o drugoj slobodi, slobodi jezika i kulture, posebice zbog toga što liberty zvukom svog korijena podsjeća na pojam knjige, knjižnice, library. Baš kao što politička sloboda implicira pravo prelaženja granice svoje zemlje, tako i jezična i kulturalna sloboda predstavljaju mogućnost prelaska granice svojih jezika i kulture. Mnogi su ljudi i dalje zarobljenici vlastitog jezika, i što ga bolje znaju, to uspješnije podižu zidove svojeg zatvora, reproduciraju one gramatičke i leksičke zakonitosti, strukturalna ograničenja i predrasude koje su im nametnute materinjim jezikom i kulturom koja in je okruživala od djetinjstva.

Čini se da ograničenje na materinji jezik nikoga nije spriječilo u stvaranju velikih djela nacionalne književnosti. Međutim, je li to zaista toliko neosporno? Je li to što su veliku rusku književnost stvorili ljudi koji su vladali najmanje dvama jezicima samo slučajnost? Dvojezičnost je faktor intelektualnog oslobođenja; bez znanja drugog jezika, ne možemo istinski znati ni vlastiti jezik, kao što ne možemo kvalitetno razmišljati jednom moždanom polutkom ili raspoznavati spektar boja i zvukova okoline jednim okom ili uhom. Dok je ruska Moskva bila isključivo rusko govorno područje, zatvorena u svojoj jednojezičnosti, nije bilo ni velike ruske književnosti. Ona je nastala tek nakon reformi Petra Velikog i nakon savladavanja stranih jezika, zbog čega je i ruski jezik u svijesti svojih građana stekao izražajnost, trodimenzionalnost. Puškin, Tjutčev, Tolstoj, Dostoevskij - svi su uživali prednosti rusko-francuske dvojezičnosti, kao što su Nabokov i Brodskij iskorištavali prednosti rusko-engleske. Sve dok ne znamo drugi jezik, nalazimo se u vlasti materinjeg i ne možemo njime ovladati, ne možemo ga govoriti - on govori nama, nesvjesno nam nameće svoja pravila i rituale. Jezična sloboda sloboda je odabira jezika za iskazivanje vlastitih ili tuđih misli i, štoviše, sloboda misliti o istim stvarima na dva jezika, misliti stereometrijski.

Stati na granicu dviju kultura je poput prelaska s monozvuka u stereosvijet; gledati jednu kulturu očima druge i gledati sve kroz dvoje oči. Utjecaj dvojezičnosti sličan je utjecaju stereoglazbe ili stereokina: zvuk i slika iznenada stječu magični volumen zato što svaki osjetilni organ ima svoju projekciju predmeta i, u suglasju, oni reproduciraju njegovu višedimenzionalnost. Kako su za zrelu 
fizičku percepciju predmeta čovjeku dani parni osjetilni organi, tako su dana i minimalno dva jezika za opsežnu „binokularnu” percepciju misli.

Možda je stereotekstualnost budućnost ljudske komunikacije, kada jezici neće služiti kao zamjena, nego kao dopuna jedan drugomu. Umjesto prije-voda, traženja ekvivalenata, pojavljuje se nova djelatnost z-druživanja i raz-druživanja jezika s ciljem izražavanja jedne misli koja na taj način otkriva nova značenja u procesu svoje jezične preobrazbe. Stereotekst je preklapanje raznojezičnih tekstova za izražajnije, „slojevito - dublje” izlaganje jedne skupine ideja.

Na taj je način sloboda, u onom obliku u kojem se javlja na granici novoga stoljeća, neodvojiva od dvojezičnosti i dvokulturnosti. Podsjećam, Kip slobode nije smješten u dubini Amerike, ili u šumama Nove Engleske, ili na ravnicama Srednjeg zapada, već na granici, na malom otoku u njujorškoj luci, okrenut prema prekooceanskim putnicima. Nisu domaći, već došljaci, lutalice, stranci, skitnice ti koji će Slobodi gledati u lice.

\section{3.}

Trebamo biti zahvalni Americi na tome što nam je podarila dvojezičnost ili, u krajnjoj liniji, jednu-ipol-jezičnost. Usprkos tomu, ne možemo ostati ravnodušni prema jezičnoj sudbini same Amerike, koja, upravo zbog pobjedonosnog širenja engleskog jezika po cijelom svijetu, počinje gubiti interes za strane jezike. Kao sveučilišni profesor prisiljen sam gledati taj žalostan pad interesa za ruski jezik. Zašto trošiti mnogo godina na ovladavanje lošim ruskim, kada je u Rusiji moguće sporazumijevati se na dobrom engleskom sa svim važnim ljudima: biznismenima, znanstvenicima, političarima? Zbog globalnog širenja engleskog jezika svoje nekadašnje značenje gube ne samo sveučilišne katedre za slavenske jezike i kulture nego i za sve druge strane jezike, osim španjolskog.

Kada me studenti pitaju zašto je potrebno učiti strane jezike, ja odgovaram: ako ni zbog čega drugog, tada zato da biste znali engleski. Zašto poznavati rusku književnost? Zato što bez poznavanja tuđega nema ni razumijevanja svojega, ne postoji ni osjećaj granice, ni sposobnost promotriti sebe iz drugog kuta. Najčešće se studenti prvi put zapitaju što su to službe riječi i vrste riječi tek u trenutku u kojem počinju učiti strani jezik. Kada sam predavao Puškina, isprva mi se 
činilo da će ga američki studenti lakše usvojiti kroz usporedbu s Byronom. Ipak, budući da nisu znali tko je Byron, na kraju je bilo potrebno objasniti ga kroz usporedbu s Puškinom.

S koje god obale ulazili u more znanja, važno je preplivati ga do kraja, do druge obale, odnosno voditi misao prema usporedbi, prema igri kontrasta i igri svjetla i sjene. Mi ne poznajemo sebe ako ne poznajemo druge. Nakon što sam se prije deset godina preselio u SAD, otkrio sam o Rusiji gotovo jednako koliko sam otkrio za četrdeset godina života u Rusiji. I to ne zato što sam ovdje imao više mogućnosti za proučavanje Rusije, nego zato što je sve ono što sam ranije proživio u Rusiji postalo znanje o njoj kroz usporedbu s drugom kulturom. Upravo kao da sam ranije imao samo polovicu dijelova slagalice iz kojih se oblikuje slika-zagonetka.

No Amerika, koja nam nudi mogućnost dvojezičnosti, sama je sve manje sklona učenju stranih jezika. To kao da je prestalo biti nužno: cijeli svijet govori njenim jezikom. Možda se čini da su anglojezični narodi u zavidnoj poziciji: u gotovo svakoj civiliziranoj zemlji oni se osjećaju kao kod kuće. Ali, s obzirom na to da engleski jezik gotovo ravnopravno pripada svima, oni su zakinuti. Svi imaju engleski jezik i još jedan vlastiti, za dublju, skrivenu, a možda i konspirativnu komunikaciju. A oni, anglojezični, imaju samo engleski. Oni govore suvremenim esperantom, a onaj im je osobni jezik, jezik za intimno čavrljanje, uskraćen. Svoj su jezik sa svima podijelili i ništa nisu dobili zauzvrat. Nijemci, Šveđani, Japanci, Indijci - svi imaju po dva jezika, a oni samo jedan.

Poznato je da se sovjetska civilizacija, nakon što se raširila na gotovo pola svijeta, srušila zbog svoje zatvorenosti: nije poznavala ništa osim sebe, nije dopuštala poglede sa strane, i upravo je to dovelo do stagnacije i pogibije. Ne bih htio da ista sudbina bezgranično pravocrtne, samodostatne civilizacije dostigne Ameriku. Osim toga, u svijetu koji se brzo razvija u dvojezičan svijet, velika opasnost za Ameriku i druge anglojezične države leži u tome što će jedino one ostati jednojezične. Jednooki u svijetu dvookih. Čak i ako jedinstvena naddržava još uvijek može predstavljati nekakvo blago za svjetsku politiku, jedinstveni nadjezik može biti dobar za sve, osim za svoje izvorne govornike, jer njima oslabljuju kodirajuće i interpretacijske sposobnosti razuma. Kako bi izbjegla tu opasnost, Amerika treba učiti strane jezike onom brzinom kojom se u drugim zemljama širi engleski. Ukoliko akcija ne bude jednaka reakciji, Amerika će po jezičnim sposobnostima, što znači i po sposobnostima mišljenja, postati jedna od najzaostalijih država kraja 21. stoljeća. Spašava je 
samo to što prima govornike drugih jezika i dopušta im da se stope s njezinom kulturom, ne tražeći zauzvrat da zaborave svoju izvornu.

Ranije se interes za Rusiju budio usporedo s idejama političkoga suparništva, grozničavošću Hladnoga rata. Danas Rusija nema tu prednost naddržave; prema tome se i popis mnogobrojnih članova momčadi slavista i sovjetologa neizbježno skraćuje - i to do granica na kojima se tom skraćivanju počinje protiviti elastičnost same ruske kulture. Jezik se neće učiti ako se na njemu nema što čitati. Jedino čime Rusija u 21. stoljeću može proslaviti svoj jezik i učiniti ga privlačnim jesu kultura i znanost. Ruski um voli djelovati suprotno pravilima, u praznini između ustanovljenih disciplina, poprijeko i ukoso. Takav način razmišljanja iznimno je tražen u suvremenoj znanosti, gdje se otkrića događaju na granicama raznih područja, gdje raste potreba za sveobuhvatnim znanjem, u „teoriji svega”. Za suvremenu znanost važna je i samoironija razuma, osvješćivanje granica racionalnosti, pokušaj uvođenja intuitivnijih, fleksibilnijih modela u sustav znanja. Vodeća su područja suvremene znanosti teorije složnosti i kaosa, u kojima su, kao što je dobro poznato, Rusi vodeći stručnjaci. Tako da vakuum koji žedno usisava u sebe sve američko ne djeluje samo u Rusiji (u ekonomiji, politici, kulturi i jeziku). I u Americi postoji svojevrsna praznina koju mogu popuniti određene postavke ruske kulture, postoji potreba za tri „i”: intuicijom, ironijom, improvizacijom.

Prema tome, ruski jezik u Americi nije otok, sa svih strana oplakivan stihijom tuđeg jezika, nego most između dviju kultura, i više od toga - on je jedno od zrcala u kojima Amerika može ugledati sebe. U toj skromnoj, no nezamjenjivoj ulozi onih koji nose zrcalo ja želim vidjeti i sebe u ovoj zemlji. Neka to zrcalo bude sastavljeno od krhotina drugog velikog kulturnog svijeta, krhotina koje još uvijek odražavaju drugu zemlju i nebesa.

\section{4.}

U povijesnom trenutku pada željezne zavjese i raspada Sovjetskoga Saveza zbio se još jedan značajan događaj: mi smo prestali biti bjegunci iz jedne države u drugu. Odjednom smo prestali biti nomadi, više nismo imali kovčege u stalnoj pripravnosti - $\mathrm{i}$ to upravo zato što se pojavila mogućnost povratka. I odjednom je postalo jasno da mi nismo ni odavde, ni odande, mi smo posve drugi Rusi i posve drugi Amerikanci, sasvim različiti i od jednih i od drugih. Mi nismo zemlja, nego 
neobičnost ${ }^{[4]}$, mi smo država u državi, umijeće gledanja svijeta tuđim i svježim, tek rođenim - mi smo hodajuća metafora, prijenos značenja, „Amerusija”, osobita kulturna zajednica koja se može raširiti, ali i nestati u iduće dvije - tri generacije.

Susret Rusije i Amerike čini jedno od možda najizražajnijih mjesta na zemlji, jedan od najizoštrenijih i najrazigranijih kulturnih reljefa. Nikad nisam vidio toliko jarkih boja kao tijekom prvih godina života u Americi. Amerika je plesala, pjenila se, blistala na podlozi te izblijedjele, dosadne boje na koju su se tijekom četrdeset godina naviknule moje oči. Nijednom rođenom Amerikancu nije dano da Ameriku vidi onako blistavom, rosnom, kristalno-prozračno-raznobojnom kakvom je vidi pridošlica s Istoka. Međutim, nakon nekoliko godina, Rusija je u mom pamćenju i mašti počela titrati takvim čudnim bojama kakve svojim očima u njoj nisam primjećivao. Nikad mi se život nije činio toliko jarkim kao u to vrijeme prijevodnih slika, vizualnih igara dviju kultura, kada se jedan sloj opažanja, onaj ruski, kontrastno slagao na drugi, onaj američki. Samo izvan Rusije, daleko od Rusije, moguće je bilo vidjeti je onakvom kakvom ju je vidio Gogol': „oh, kakva je blistava, čudesna ta daljina o kojoj svijet ništa ne zna! Rusijo!.... ${ }^{[5]}$ Kakva bi bila Rusija u našoj duši bez tih gogoljevskih svjetlucajućih boja, vrtložnih linija i veselih zvona, a njemu su se oni javili na drugom kraju Europe, u Rimu, gdje je pisao svoju „pticu trojku”.

Riječi „emigracija” i „dijaspora” nejasne su riječi kojima se ne može prenijeti iskustvo čovjeka na granici dviju kultura. Bolje je sjetiti se Tjutčeva:

O pronicljiva dušo moja!

O srce, prepuno tjeskobe,

O, kako ti biješ na pragu

Svojevrsnog dvojakog postojanja!..[6]

Prag dvojakog postojanja - tako se zove naše stanje između dva svijeta.

Svojevremeno je Nina Berberova izjavila: „Mi nismo u progonstvu, mi smo u poslanstvu” (Lirska poema, 1927.). Htjela je reći da emigracija ne treba uvrijeđeno gledati u prošlost, već u budućnost, i to s nadom da svojoj novoj domovini nosi važnu vijest iz stare domovine, upozorenje i upute. Meni se ipak čini da ni riječ „poslanstvo” više ne odgovara u potpunosti današnjem položaju 
Amerusa, ruskog Amerikanca. I „progonstvo” i „poslanstvo” govore o nama, s negativnom ili pozitivnom konotacijom, u kontekstu bivše domovine, a za nas je u jednakoj mjeri značajna i nova domovina, ona je čak dvostruko značajna - upravo je u našoj pripadnosti objema državama osobitost našeg položaja među njima.

Progonstvo i poslanstvo jednosmjerno su kretanje iz jedne točke u drugu. Sada, kada su oba smjera otvorena te je moguće slobodno se kretati u oba pravca, posebno je važan intenzitet života ovdje i sada, na sjecištu dviju kultura, koje jedna drugu zasjenjuju, te našem životu pridaju dvojaki ritam, obojenje i kontrast. Dvojaki život - eto, tako to možemo nazvati; na sjecištu dvojakog bitka svi doživljaji boja, zvukova, mirisa, glasova, jezika postaju dvostruko izraženiji. Svijet postaje „Čudnim, zavinutim u šarenu maglu” (A. Blok). Prema Viktoru Šklovskom u članku Umjetnost kao postupak, cilj je umjetnosti izvesti našu percepciju iz automatizma percepcije, prekinuti inerciju postojanja, otkriti neobično u onome što nam se čini svakodnevnim. „Automatizacija proždire stvari, haljinu, namještaj, ženu... (...) Život kao da i ne postoji. I evo zbog toga, da bi se vratio osjećaj života, da bismo opet mogli osjetiti stvari, da bismo kamen učinili kamenom, postoji ono što se naziva umjetnošću. ${ }^{\natural 7]}$

No iz istog tog razloga postoji i naš neuobičajeni dvojaki život, koji je sličan umjetnosti utoliko što i on očuđuje stvari, tjera nas da ih vidimo kao prvi put. To što smo stranci i jest način očuđenja, sam je naš život u inozemstvu postupak. To što govorimo stranim jezikom potencijalni je način obnove oba jezika, osmišljavanje nečega što u njima dotada nije postojalo - kao što je Nabokov upisivao ruski jezik u engleski, a Brodskij - engleski jezik u ruski. Već i djelomična pripadnost drugoj kulturi oslobađa od onih nametnutih ideja, mitskih kompleksa, psiholoških manija i fobija, kolektivnih predrasuda, koje neizbježno usvajamo iz svoje kulture te tako ostajemo njezinim dužnicima. Dvokulturnost je uvjet za oslobođenje od obje kulture te pruža mogućnost dubljeg pronicanja u svaku od njih. Kako je pisao drugi teoretičar, Mihail Bahtin, „izvannalaženje je najmoćniji pokretač razumijevanja. Tuđa kultura u najvećoj se punini i dubini otkriva tek u očima druge kulture. Mi tuđoj kulturi postavljamo nova pitanja, kakva ona sama sebi nije postavljala... ${ }^{\text {} 8]}$

Moć Amerike i izvor njezina nevjerojatnog rasta jest u tome što ona prima u sebe razne tuđine, i mi smo dio onoga što je njoj tuđe, pokretač njezina samorazumijevanja. Upravo zbog toga što mi nismo ni odande ni odavde, omogućeno nam je da obje države vidimo kao da ih gledamo prvi put: 
Ameriku očima Rusa i Rusiju očima Amerikanca. Automatizacija nam prijeti u manjoj mjeri nego starosjediocima tih kultura, zbog toga što uobičajenosti jednog načina života pršte neobičnošću, različitošću od drugog; jedna sastavnica Amerusije izvlači iz automatizma drugu. Rijetko se suočavamo s automatizacijom, češće sa stresom, prezasićenošću kontrastima, prevelikim pritiskom na mjesta na kojima se savijamo.

Naravno, takvo dvojako postojanje podrazumijeva i veliki rizik zato što tamo gdje postoji množenje, postoji i dijeljenje. Sposobnost dvojezičnosti, koju stječemo na granici kultura, lako se pretvara u polupoznavanje stranog jezika i poluzaborav materinjeg. Nama nisu poznati samo obrasci snažnog govora, čija su izražajna sredstva udvojena dodirom jezika, već i primjeri polovičnog govora, smjese žargona, gdje od oba jezika ostaju tek komadići njihova katastrofalnog sraza. Kada prelazimo granicu između kultura, lako je zaglaviti u ničijoj zemlji, gdje nijedna od tih kultura nije ostavila ništa osim smeća i otpada.

Udvojeno ili prepolovljeno veoma su slični pojmovi, ali posve različite računske radnje. Nad nama cijelo vrijeme visi pitanje: udvajamo li mi svoj kulturni imetak ili ga prepolovljujemo? Je li rezultat našeg pripadanja dvjema kulturama više ili manje od jedan?9]

No bez obzira na to kakav bio odgovor na ovo pitanje, očito je da se nalazimo u području najvećeg kulturnog rizika, gdje su ulozi dvostruki, što znači da rastu i mogućnost dobitka i mogućnost gubitka. Izbor je veoma velik, intenzitet iskustva veoma je visok. Naša je duša „stanovnik dvaju svjetova" i ona mora proživjeti i muku toga raz-dvajanja, i praznik toga u-dvajanja. Mi smo drugačiji i prekomjerni objema kulturama. Mi nismo ni u progonstvu ni i poslanstvu - mi smo u potrazi. Mi smo u poigravanju i treperenju smisla, mi smo citati jedne kulture u tekstu druge, mi na sebi nosimo nevidljive navodne znakove. Mi smo na pragu dvojakog postojanja. Mi smo s obje strane, dvaput smo stranci...

\section{5.}

I u isto vrijeme dvaput smo svoji, nalazimo se u najnježnijoj, najintimnijoj točki dodira dviju kultura, gdje su one posve očarane jedna drugom. U svakom organizmu, ne samo biološkom, već i kulturnom, postoje tjelesne stanice (živčane, koštane, mišićne i dr.) i spolne stanice. Ono što se 
tradicionalno naziva emigracijom, zapravo je ejakulacija, izbacivanje stanica jedne kulture u utrobu druge, začetak novih organizama.

Po najnovijim teorijama, proces širenja i razmnožavanja jedinica kulturnih informacija, tzv. memova, sličan je procesima rasprostranjivanja gena. Termin mem prvi je upotrijebio engleski biolog Richard Dawkins u knjizi Sebični gen (1976.), koja je postala znanstveni bestseler i klasik suvremene teorije evolucije $!^{[10]} \cup$ njoj Dawkins dokazuje kako uz gene, kao nositelje bioloških informacija, postoje i nositelji kulturnih informacija, koji su također skloni samoumnažanju te su podložni zakonima Darwinove evolucije. Prema analogiji s genima, Dawkins te jedinice kulturnog pamćenja naziva memovima. Oni streme k beskonačnom samoumnažanju i za to se koriste knjigama, pjesmama, predstavama, političkim ideologijama, medijima itd. Primjer su takvih memova primjerice krilatice, slogani, književni zapleti, vizualni prikazi, glazbeni motivi, moda, kuharski recepti, matematičke formule... Sve u svemu, cijelu ljudsku povijest možemo opisati kao evoluciju memova, njihovu borbu za preživljavanje, širenje, pokoravanje umova, ulazak u duhovnu i materijalnu kulturu.

No s obzirom na to da se ljudski geni rasprostranjuju upravo spolnim putem, nikako ne smijemo zaboraviti erotsku stranu te „kulturne genetike”, kojom se bavi nova znanost memetika. Ako memetika, kojom se danas bave uvaženi biolozi i kulturolozi, nije tek metafora za genetiku, tada i eros kulturnih privlačenja, mimetičkih prodiranja, informativnih funkcija, ironična oštrina jezičnih i intelektualnih iskustava u području kontakta između kultura, također nisu samo metafora.

U 20. stoljeću dogodila se, može se reći, seksualna revolucija u životu kultura - burni susreti, presijecanja, miješanja, oplođivanje. Spolne stanice, gamete, imaju drugačiju pokretačku energiju od tjelesnih: one se „izbacuju” iz jednog organizma i „šalju” u drugi kako bi stvorile novi život. Mi smo kometi koji putuju iz jednog zvjezdanog sustava u drugi; mi smo gamete koje prenose informaciju iz jednog organizma u drugi. Mi nismo jednostavno „u progonstvu i poslanstvu”, mi smo u snošaju i začetku, mi smo stanice koje jedna država izbacuje iz sebe da bi začela novi život u utrobi druge države. Ono što se naziva dijasporom nije tek samostalni kulturni organizam, koliko orgazam - funkcija uzajamnog poznavanja i pronicanja različitih organizama. Dvojaki život, na čijem pragu vodimo našu borbu, ljubavna je groznica dviju kultura, grčenje njihove sreće ili, u slučaju nesreće, bol njihova razdvajanja, inkompatibilnost dvaju tkiva. 
„Amerusija” je složeno ime; ime strasti koja objedinjuje dvije velike kulture i ime genetske opasnosti... Teško je predvidjeti tko ili što će se izroditi - genij ili čudovište, utjelovljenje utopije ili razorna himera. No čak i te greške i gubitci kojima je ispunjeno sjedinjenje dviju kultura mogu postati moćan pokretač evolucije. Migracija je najučinkovitiji način evolucijskog razmnožavanja kultura, stvaranja novog genetskog materijala putem miješanja informacija koje se događa predavanjem kromosoma jedne kulture drugoj. Same pogreške - sistematske, društvene, profesionalne, karijerne, lingvističke, ceremonijalne - koje radimo pri prijelazu iz kulture u kulturu, u prijevodu s jednog jezika na drugi, mogu odigrati ulogu kreativne mutacije. Migracija je kulturna mutacija, promjena nasljednih karakteristika kao rezultat obnavljanja i narušavanja unutar informacijskog koda, kako u kulturi pošiljatelju, tako i u kulturi primatelju. Mutacije u prirodi i migracije u kulturi odlučujući su faktori evolucije te dovode do pojave novih vrsta, osnova su promjenjivosti u sustavima života i svijesti koji se neprestano razvijaju.

Kultura je igra pokvarenog telefona: pogreške se množe, a kao rezultat na drugom se kraju rađa nova poruka. Mi ne trebamo računati na to da će nas naši prijašnji ili novi sunarodnjaci u potpunosti saslušati i razumjeti - kao i uvijek, nešto će se iskriviti. No kao karika u lancu pogrešaka, mi imamo pravo na nestalnosti takve dvojake sudbine, koja prolazi područjem gluhoće i nepotpunog razumijevanja. Na točki kulturnog dodira Rusije i Amerike događa se golema količina pogrešaka, tamo su pucketanje i škripa slični buci iz vremena emitiranja „Slobode” iza željezne zavjese. No ono što procuri širi se dalje, dobiva novi zvuk i u svemu je rečenom najveća ljepota nepredvidivost.

U New Yorku, 3. prosinca 2000.

Izvor: Ėpštejn, Mikhail. 2004. Znak_probela. (O buduščem gumanitarnyh nauk). Novoe literaturnoe obozrenie, 2004, str. 807-823.

Preveli: Marija Bakula, Mane Boca i Paula Čivrak 
[1] Nagrada „Liberty” dodjeljuje se godišnje od 1999. godine dvama laureatima za „izvanredan doprinos rusko-američkoj kulturi i razvoju kulturnih odnosa Rusije i SAD-a”. Uručenje nagrade 2000. godine održalo se 3. prosinca u New Yorku (Merkin Hall), a jedan je od dobitnika bio Mihail Épštejn (op. prev.).

[2]Ruska riječ sobornost' označava „ruski neprevodivi antipod zapadnome pojmu pojedinca i identiteta” (v. Boym, S. 2006. Mitologija svakodnevnog života u Rusiji. Prev. B. Romić, „Kolo”, br. 3). Riječ potječe od sobor (skup, sabor ili katedrala) i antiteza je vlasti i formalne duhovnosti. Kako navodi S. Boym, „Sobornost” je radikalno antiikonografska, antiretorička i antikonvencionalna. Ljubav i sloboda nisu određene; one nisu definirane u odnosu prema jeziku ili konvenciji. Istina duhovnosti nema formalnih atributa. Sobornost' i istinska duhovnost mogu jedino biti ali ne i značiti; mogu se intuitivno osjetiti mistički, ali ne i čitati ili tumačiti. Prema tome shvaćanju, istinska zajednica, poput simbola, nadilazi jezik i ikonografiju" (ibid.). Riječ se obilato koristi i u tekstu Rusija kao podsvjesno Zapada Borisa Groysa (op. prev.).

[3]Dostojevski, Fjodor Mihajlovič. 2004. Braća Karamazovi. Prev. Z. Crnković. Zagreb: Globus media. Str. 122 (op. prev.).

[4]Autor se poigrava leksičkom sličnošću dviju riječi: u ruskom jeziku riječi zemlja i neobičnost imaju isti korijen - stranna i strannost' (op. prev.).

[5]Gogolj, Nikolaj Vasiljevič. 2004. Mrtve duše. Prev. Z. Crnković. Zagreb: Globus media. Str. 183 ( op. prev.).

[6]Tjutčev, Fedor Ivanovič. O veščaja duša moja... (prijevod naš, op. prev.).

[7]Šklovskij, Viktor. 1985. Umjetnost kao postupak. U: Beker, M. (ur.) Suvremene književne teorije. Zagreb: Sveučilišna naklada Liber. Str. 125.

[8] Bahtin, M. 1979. Otvet na vopros pedakcii „Novogo mira”. U: Bahtin, M. 1979. Ėstetika slovesnogo tvorčestva. Moskva: Iskusstvo. Str. 334-335 (prijevod naš, op. prev.).

[9] U originalu - men'še edinicy, što je ruski naslov eseja Brodskoga Less Than One (op. prev.). 
[10] Dawkins, R. 1976. The Selfish Gene. Oxford: Oxford University Press; Blackmore, S. 2000. The Meme Machine. Oxford: Oxford University Press.

\section{(c) (i) (9)}

Creative Commons Attribution-NonCommercial-NoDerivatives 4.0 International License 